\title{
Kampens nya former. Klasskamp och klasstruktur sedan de vilda strejkerna
}

\author{
Magnus Granberg
}

SAMMANDRAG: I sin artikel analyserar Magnus Granberg förändringar i klasskampens former mot bakgrund av förändringar i det svenska samhällets klasstruktur. Genom att fokusera klasskampens kvalitativa formförändringar går analysen i polemik mot en företrädesvis kvantitativ tradition i svensk och internationell forskning om arbetskonflikter. Inom ett differentierat konfliktmönster där arbetare kombinerar vad Granberg identifierar som fordistiska, logistiska och reproduktiva maktresurser uppstår nya kampformer, här illustrerat av den "kollektiva uppsägningen" vars slagstyrka inte minst härrör från tilltagande varufiering av offentliga tjänster. För att förstå förändringarna i konfliktmönstret används kvantitativa och kvalitativa data som belyser hur klasstrukturens och kapitalets omvandling aktualiserar nya proletära medvetande- och kampformer. I ett komparativt perspektiv kan det framväxande svenska konfliktmönstret sägas motsvara utmärkande drag i det internationella kampuppsving som skett efter den ekonomiska krisen 2007-2009.

NYCKELORD: klasskamp; arbetskonflikt; klasstruktur; kampformer; strejkformer; maktresurs; arbetarklasser.

PUBLICERINGSHISTORIK: Originalpublicering.

MAGNUS GRANBERG är sociolog och lektor vid Mittuniversitetet.

E-POSTADRESS: magnus.granberg@miun.se

FÖRSLAG PÅ KÄLLANGIVELSE:

Granberg, Magnus (2020) "Kampens nya former. Klasskamp och klasstruktur sedan de vilda strejkerna”, i Arkiv. Tidskrift för sambällsanalys, nr I2, s. I07-139.

DOI: https://doi.org/IO.I3068/2000-6217.I2.3

(C) Magnus Granberg/Arkiv förlag \& tidskrift 2020 (publicerad ıo december 2020)

Artikeln distribueras enligt en upphovsrättslicens från Creative Commons:

Erkännande-Ickekommersiell-IngaBearbetningar 3.o Unported, som medger fri ickekommersiell användning och spridning i oförändrat skick så länge källan anges. 
Arkiv. Tidskrift för samhällsanalys är en sakkunniggranskad vetenskaplig tidskrift för samhällsvetenskap och historia. Samtliga artiklar publiceras fritt tillgängliga på:

$$
\text { www.tidskriftenarkiv.se }
$$

Beständig länk, DOI: https://doi.org/IO.I3068/2000-62I7

Den här artikeln finns tillgänglig i följande format:

PDF: via beständig länk, DoI: https://doi.org/IO.I3068/2000-6217.12.3

TRYCK: ingår i bokutgåva av numret, ISBN: 978 9I 79243388

Grafisk utformning och sidnumrering är identisk i pdf och tryck.

Samtliga artiklar i nr I2 (2020) nås via beständig länk, DOI: https://doi.org/IO.I3068/2000-62I7.I2

Arkiv. Tidskrift för samhällsanalys

ISSN: 2000-62I7 (för elektronisk resurs)

ISSN: 2000-6225 (för tryckta nummer)

ges ut av

Stiftelsen Arkiv för främjande och spridning av samhällsvetenskaplig och historisk forskning

genom

Arkiv förlag \& tidskrift

Box 1559

SE-22I OI Lund

BESÖK: L Gråbrödersg 3 c, ipg

TEL: 046-I3 3920

ARKIV FÖRLAG: arkiv@arkiv.nu·www.arkiv.nu

TIDSKRIFTEN ARKIV: red@tidskriftenarkiv.se.www.tidskriftenarkiv.se

ANSVARIg UTGIVARE \& CHEFREDAKTÖR: Sven Hort

Administrativ Redaktör: David Lindberg

REDAKTörer: Per Dannefjord, Lisa Kings, Zhanna Kravchenko, Anna-Maria Sarstrand Marekovic 


\title{
Kampens nya former. Klasskamp och klasstruktur sedan de vilda strejkerna
}

\author{
MAGNUS GRANBERG
}

\section{Inledning}

Klassanalysen beskrevs en gång ha två huvuduppgifter. Den skulle undersöka klasstrukturen och dess effekter på människors relationer och livsvillkor, och den skulle undersöka klasskampen och relaterade mönster av sociala motsättningar. ${ }^{1}$ Utan att göra anspråk på fullständighet ska jag i den här artikeln utforska klasskampen i Sverige i relation till förändringar i klasstrukturen.

Jag använder ordet "klasskamp" synonymt med "arbetskonflikt": konflikter som kommer till uttryck i exempelvis strejker. Problemen med en sådan reduktionism återkomer jag till nedan, men i den vaga marxistiska jargong där ordet "klasskamp" mestadels förekommer preciserar "arbetskonflikt" någonting viktigt: ett brott i relationen mellan arbete och kapital. Egentligen kan alla sociala praktiker betraktas som klasskamp i den meningen att de bidrar till att antingen reproducera eller omvandla denna relation, ${ }^{2}$ och det finns utöver strejker en rad andra sorters kollektiva aktioner, däribland kravaller, gatudemonstrationer och ockupationer. Men av pragmatiska skäl och mot bakgrund av arbetskonflikternas direkta koppling till själva produktionsförhållandet betraktar jag "klasskamp" som liktydigt med "arbetskonflikt".

I. Therborn (I975), s. 3-4. Se även Therborn (2018 [I98I]).

2. Carchedi (1987). 
En dominant tradition inom strejkforskningen präglas av ett kvantitativt perspektiv, medan jag i stället ska belysa klasskampens kvalitativa förändringar. Bruket av kvantitativa data är oundvikligt i en analys av historiska tendenser, men jag vänder mig mot det metodologiska antagandet att begreppet "strejk" betecknar något likformigt, det vill säga något homogent och oföränderligt genom tid och rum. Arbetarklasser (i plural) och arbetarnas maktresurser omvandlas dock över tid, vilket leder till olika strejkformer.

Jag urskiljer i min analys mönster i arbetskonflikternas utveckling under det senaste halvseklet och diskuterar hur dessa mönster avspeglar förändringar i samhällets klasstruktur. Å ena sidan förekommer "välfärdsstrejker", som till synes inte slår mot själva värdeproduktionen i marxistisk mening, men som begagnar sig av reproduktiva maktresurser. Dessa arbetare är strategiskt lokaliserade i en social arbetsdelning, varför deras kollektiva aktioner (till exempel inom barnomsorg och skolväsende) kan orsaka störningar som indirekt slår mot värdeproduktionen. ${ }^{3} \AA$ andra sidan förekommer "logistikstrejker" som slår mot vidsträckta värdekedjor där produktionen av en vara sker i sammanlänkade led vid mer än en arbetsplats. Dessa former kompletterar en traditionell "fordistisk" strejkform som slår direkt mot värdeproduktionen. Mot bakgrund av denna analys utvecklar jag en typologi med utgångspunkt i fordistiska, reproduktiva och logistiska maktresurser.

Sedan 1990-talet har en framträdande åsikt i akademisk och politisk debatt varit att betydelsen av klass har minskat. En variant på temat är den serie av påståenden som motiverade nyorienteringen av europeisk socialdemokrati under epitet som "tredje vägen" och "die neue Mitte": Industriarbetarna, som betraktades som arbetarklass par excellence, hade marginaliserats i avancerade och i allt högre grad postindustriella ekonomier; den motsvarande ökningen av välmående skikt av medelklasskaraktär hade skapat ett tvåtredjedelssamhälle; och dessa förändringar hade gjort socialdemokratins traditionella fokus på jämlikhet och omfördelning otidsenligt. ${ }^{4}$ Mindre uppmärksamhet har ägnats åt frågor om hur etableringen av senmodernitetens klasslösa självbild hängde samman

3. Silver (2003), s. II7.

4. T.ex. Giddens (1999). För ett genmäle, se t.ex. Svallfors (2004). 
med den markanta nedgång i antalet arbetskonflikter (särskilt strejker) som samtidigt ägde rum.

En utgångspunkt inom marxistisk teori är att sociala föreställningar inte existerar oberoende av hur samhället så att säga presenterar sig självt. I den meningen slutade under I980-talet många samhällen att te sig som samhällen präglade av klass. I flertalet avancerade ekonomier föll strejkaktiviteten till försumbara nivåer. ${ }^{5}$ Liksom Fukuyama lät sovjetsamhällenas upplösning motivera proklamationen om "historiens slut", bekräftade klasskampens minskade synlighet idén att klass var passé. Om detta mestadels var en omedveten mental process fanns det också explicita homologa idéer om sambandet mellan klasskamp och klasstruktur kortfattat: att klasstrukturen av i dag inte erbjuder de möjligheter till klasskamp som rådde under merparten av 1900-talet. ${ }^{6}$ Klassamhället skulle enligt denna syn ha kristalliserats. Dess nya struktur skulle hindra klass från att dynamiskt aktiveras som klasskamp.

Jag menar att de motstridiga tendenser som ryms i förhållandet mellan klasskamp och klasstruktur visar att klasskampen inte tynar bort. Min tes är att kampens former har förändrats, och i Sverige låter de frambrytande konfliktformerna ana konturerna av ett nytt globalt uppsving i klasskampen. Närmare bestämt uppstår det nya aktionsformer där arbetare kombinerar fordistiska, logistiska och reproduktiva maktresurser, här illustrerat av den kollektiva uppsägningen, vars slagstyrka inte minst härrör från en tilltagande varufiering av offentliga tjänster.

\section{Kort om institutioner}

Det kan verka märkligt att inte sätta arbetsmarknadsinstitutioner i främsta rummet $\mathrm{i}$ en analys av klasskampens långtidstrender, kanske särskilt i ett land som Sverige där "parternas" utrymme att utan statlig inblandning reglera arbetsmarknaden har varit jämförelsevis stort. Men eftersom klasskampen är förhållandevis frikopplad från den överbyggnad som består av arbetar- och arbetsköparorganisationer, ingångna avtal och arbetsmarknadslagstiftning, och eftersom fokus i denna studie ligger på

5. van der Velden m.fl. (2007).

6. Ett inflytelserikt exempel är Brown (1990). 
kampformernas förändring i relation till klasstrukturens förändring, kan arbetsmarknadsinstitutioner och deras förändring förstås som eftersläpande i min analys.

Därmed inte sagt att klasskampen utvecklas oberoende av den institutionella och politiska omgivningen. Välfärdens expansion, Saltsjöbadsavtalet, socialdemokratiska regeringar och en jämnare fördelning av produktionsresultatet borgade för övergången till en lugnare arbetsmarknad efter 1945, till exempel. Efter kriget avlöste dessutom de tillväxtstarka "gyllene åren" de ekonomiskt och politiskt krisartade mellankrigsåren. Men när kristendenser återkom vid slutet av 1960-talet ökade strejkaktiviteten nästintill överallt i den avancerade kapitalismen, vilket skvallrar om klasskampens relativa autonomi i förhållande till nationella institutioner. En maktkamp och en rörelse bort från "den historiska kompromissen" inleddes.

Det jämviktsläge som hade präglat den tidiga efterkrigstiden i Sverige rubbades vid 1960-talets slut, först av en facklig offensiv, sedan av en motrörelse från arbetsköparhåll. Under senare delen av i990-talet etablerades ett nytt jämviktsläge, om än med en svagare facklig part. ${ }^{7}$ Fackets offensiv tog sig bland annat uttryck i 1970-talets arbetsrättslagstiftning med begränsade (MBL, LAS) såväl som långtgående (löntagarfonder) krav på arbetarinflytande i näringslivet. Arbetsköparoffensiven tog sig uttryck dels i opinionsbildning, dels i en mer aggressiv avtalspolitik i storkonflikten I980 och i de konfliktfyllda avtalsrörelserna under början av I990-talet.

I kontrast till flera västeuropeiska länder kunde fackföreningarna i Sverige i viss mån motstå offensiven på arbetsmarknadsområdet (politiskt gick utvecklingen däremot i samma nyliberala riktning som annorstädes). Arbetsköparnas krav på att slopa centrala avtal till förmån för en långtgående decentralisering av lönebildningen förverkligades inte (även om en decentraliseringstrend inleddes under 1980-talet), och facken bevarade under 1980- och $1990-t a l e n$ "en betydande konfliktkapacitet", enligt fackföreningsforskaren Anders Kjellberg. Under det nya jämviktsläge som etablerades under andra halvan av I990-talet var den fackliga organisationsgraden och kollektivavtalens täckningsgrad fortsatt höga, och

7. Kjellberg (2016). 
centralavtalen bestod. Den fackliga parten var dock försvagad jämfört med på 1970-talet, vilket framgår av bland annat en lägre organisationsgrad bland privatanställda och tendensen mot "sifferlösa" centrala avtal.

Partsorganisationernas maktspel kan ses som motstridiga försök att anpassa arbetsmarknadens institutioner till förändringar och omslag i klasskampen. ${ }^{8}$ Vad gäller fackets arbetsrättsoffensiv bör betonas att de paradigmatiska vilda strejkerna (bland hamn-, gruv- och skogsarbetare) genom sin rådsdemokratiska organisation förkroppsligade kraven på ekonomisk demokrati. I dessa konflikter aktualiserade tendenser mot "reell underordning", som jag här kommer att behandla som särskilt relevanta effekter av förändringar i samhällets klasstruktur, ${ }^{9}$ strider om kontrollen över det direkta arbetet. Krav på arbetarinflytande drevs fram underifrån och omvandlades till en specifik facklig-politisk strategi som kulminerade med löntagarfondsförslaget. ${ }^{10}$ Arbetsköparnas strävan att decentralisera lönebildningen, samtidigt som de understödde ett mindre uppmärksammat men desto mer framgångsrikt inslag i 1970-talets arbetslagar (införandet av ett hårdare sanktionssystem mot olovliga strejker), utgjorde på samma sätt ett försök att tämja och kväsa strejkrörelserna. ${ }^{\text {II }}$

Men det var knappast ny lagstiftning som orsakade de vilda strejkernas kraftiga nedgång efter 1990. Det internationella strejkuppsvinget efter 1968 mattades av efter mitten av 1970-talet, mycket till följd av den avindustrialiseringstrend och de kriser som på allvar började prägla den avancerade kapitalismens klasstruktur. I och med 1990-talskrisen och den åtföljande ökningen av arbetslösheten rättade sig Sverige något försenat i det nyliberala ledet. ${ }^{\mathrm{I}}$ Denna utveckling måste också ses i ljuset

8. Schiller (1988).

9. Granberg (2016). Karl Marx skiljde mellan arbetets formella och reella underordning. Formell underordning innebär att tidigare självständiga producenter anlitas som lönearbetare under oförändrade organisatoriska och tekniska villkor. Reell underordning sker när produktionen autonomiseras och arbetarna förlorar den direkta kontrollen över den. Se Marx (1975), s. 579ff.

IO. Granberg (20I2). Vi ser här hur en social form (rådsdemokratisk strejkorganisation) förebådar och aktualiserar en tankeform (den politiska visionen om ekonomisk demokrati). Pionjärstudien inom det marxistiska forskningsfält som studerat sådana här processer är Sohn-Rethel (I978).

II. Järhult (I982), s. 7-8. Jfr förslagen till utökad strejkrätt i Korpi (I974).

I2. Granberg (20I6); Lundh (2002), s. 26I; Stokke \& Thörnqvist (200I). 
av vissa LO-förbunds alltmer undergivna attityd och ovilja att använda konfliktvapnet.

Om arbetsmarknadsinstitutioner således släpar efter klasskampen kan de å andra sidan påverka kampformerna i ett senare skede, liksom institutionerna förknippade med Saltsjöbadsavtalet bidrog till de vilda (av fackföreningar oberoende) strejkerna, som fick sitt genombrott först tre årtionden senare. Som vi ska se har också trenden mot en decentraliserad lönebildning slagit om till ett betydande incitament för arbetare inom offentlig sektor att genomföra lokala och informella kampaktioner, vilket syns tydligast i sjuksköterskors kollektiva uppsägningar. Och arbetsköparnas ökade möjlighet, sedan 1970-talet, att bestraffa arbetare som strejkar vilt skulle kunna leda till att uppsägningsaktionen sprider sig på svensk arbetsmarknad (konflikten inom sophanteringen i Stockholm under 2017 tyder i viss mån på det).

I dag är dock nya arbetslagar i annalkande, delvis motiverade av vissa arbetares nyvunna förmåga att framkalla logistikkaos. Sedan början av I990-talet har arbetsköparna strävat efter att begränsa konflikträtten, det socialdemokratiska partiet har anammat en del av deras krav, och fackförbund inom industrin har medverkat till att delvis uppfylla dem avtalsvägen. ${ }^{13}$ Under 2019 enades centralorganisationerna om vissa inskränkningar av rätten att vidta konfliktåtgärder, vilka kort därpå blev lag. Förändringarna begränsar dock främst de mindre och särskilt stridbara fackförbunden. Kvarstår gör arbetsköparnas krav på ett allmänt förbud mot så kallade oproportionerliga stridsåtgärder och solidaritetsaktioner.

\section{Forskningsläge, metod och material}

Ett antagande om likformighet har präglat stora delar av den västerländska och svenska forskningen om strejker. I en inflytelserik komparativ studie 1960 menade Arthur M. Ross och Paul T. Hartman att strejken hade institutionaliserats i den organiserade kapitalism som växte fram under efterkrigstiden och att den nu höll på att "vittra bort". ${ }^{14}$ Ross och Hartman tog i synnerhet fasta på antalet strejkdagar, och tillsammans

13. Junesjö (1998). Se även www.kurt.nu.

I4. Ross \& Hartman (1960). 
med antalet strejker och deras intensitet (antal strejkande arbetare) har detta standardmått fungerat som utgångspunkt för historisk och komparativ forskning. När man talat om strejkernas former har man således framför allt avsett förändringar i dessa tre dimensioner. ${ }^{15}$ När strejker fick ett uppsving under slutet av 1960-talet, i strid med Ross och Hartmans tes, förändrades inte den komparativa forskningens kvantitativa fokus, trots att dessa strejker skiljde sig markant från strejkerna under mellankrigsåren. ${ }^{16}$

Ett kvantitativt fokus kom att prägla också svensk komparativ forskning om strejker och arbetskonflikter. ${ }^{17}$ En kvalitativ fallstudietradition har förvisso uppmärksammat strejkernas former i en vidare bemärkelse, ${ }^{18}$ men detta kan alltså inte sägas om den övergripande komparativa forskning som uttalat sig om långtidstrender.

Impulsen att kvantifiera strejker och andra kollektiva aktioner bör ses i ljuset av de västeuropeiska staternas upplevda behov att, efter I8oo-talets första proletära revolter, förstå och hantera folkliga rörelser. Den statliga strejkstatistik som resulterade ur sådana strävanden är i många länder fortfarande en primär indikator i akademiska studier av strejkaktivitet. Det har bäring på frågan om huruvida klasskampen tynar bort i det senmoderna samhället. Om strejkfrekvensen antas direkt avspegla klasskampen verkar detta utan tvivel vara fallet - antalet strejker har sedan mitten av I970-talet sjunkit i avancerade ekonomier. ${ }^{19}$ Men på vilken grund jämställs exempelvis skogsarbetarstrejken 1975 med Kommunalstrejken 2003? De räknas bägge som en strejk, och visst finns det likheter: antalet strejkdagar var i båda fallen relativt högt och konflikterna var relativt utdragna. Avgörande skillnader står dock att finna i till exempel strejkorganisationen. Lite hårdraget står här gräsrotskontroll mot facklig toppstyrning. Just deras gräsrotsdemokratiska former gör 1970-talets strejker till en distinkt rörelse som bland annat aktualiserade frågan om "ekonomisk

I5. T.ex. Shorter \& Tilly (1974).

I6. T.ex. Crouch \& Pizzorno (I978); van der Velden m.fl. (2007). Jfr Brenner, Brenner \& Winslow (2010).

I7. Korpi (I978), (I98I); Thörnqvist (I994).

I8. T.ex. Fantasia (I988); Israel (I964).

I9. van der Velden (2016). 
demokrati”. ${ }^{20}$ Vidare mobiliserade de varuproducerande skogsarbetarna helt andra maktresurser än de reproduktiva kommunalarbetarna.

Det finns numera vissa tecken på att den komparativa forskningen tar strejkernas föränderliga former på större allvar. Inte minst görs detta med hänvisning till en "repertoar" av folkliga aktionsformer, ett populärt begrepp inom forskningen om sociala rörelser. ${ }^{21}$ Men vad avses med en sådan repertoar? Dessvärre blir även detta begrepp underställt en positivistisk ambition att skapa abstrakta kategorier över olika aktionsformer, med resulterande taxonomier där "strejk" figurerar jämte "blockad", "fabriksockupation" etcetera. Ett antipositivistiskt alternativ kan hämta inspiration från Marx’ analys av kapitalformer och penningfunktioner, det vill säga från konkreta former och funktioner som gör ett socialt fenomen och dess inre dynamik distinkt. ${ }^{22}$ Kort sagt: arbetare mobiliserar olika typer av maktresurser som har bestämda funktioner inom en distinkt strejkform.

En sådan analys skulle också överensstämma med vissa tongivande texter inom marxistisk politisk teori. Där står just klasskampens formförändringar, särskilt genomslagen för nya kampformer, i fokus. Marx prisade sålunda Pariskommunen som "den äntligen upptäckta [...] formen" för arbetets frigörelse. ${ }^{23}$ Han såg politik som kollektiv "självkritik", en självomvandlande praktik där kamp-, organisations- och medvetandeformer, liksom de samhällsområden som politiseras, är stadda i ständig förändring. ${ }^{24}$

Ett fokus på kampformernas kvalitativa förändringar kan kombineras med perspektiv på arbetskonflikter som belyser hur "proletarisering" och "reell underordning" motiverar grupper av arbetare att under olika perioder ta strid mot sina arbetsköpare. Detta är de metodologiska antaganden som ligger till grund för min avgränsning av denna studie av

20. Granberg (20I2); Järhult (1982).

2I. Kelly (2015); Vandaele (2016). Jfr Tilly (1976).

22. Marx (2018), (1973).

23. Marx (I98I), s. 74. Inom forskning om sociala rörelser och kollektiva aktioner motsvaras marxistiska förståelser av "form" av Tillys historiska analys, se Tilly (I976). Som emellertid framgår av diskussionen ovan är min åsikt att en marxistisk analys måste gå bortom abstrakt kategoriserande för att bestämma de olikartade funktioner som ligger till grund för olika strejkformer.

24. Kouvelakis (2003), s. 309-3I4. 
klasskampen till en studie av det frambrytande mönstret av kampformer på arbetskonflikternas område.

Avgränsningen har sina nackdelar. En av dem är att kollektivt handlande, som står i centrum för min analys, alltid betecknar en mer vidsträckt och komplex social praktik, som numera ofta kallas "social rörelse". För att ta ett inhemskt exempel har det sedan den senaste internationella ekonomiska krisen utbröt vuxit fram en urban rättviserörelse med "orten" som förenande referens. ${ }^{25}$ En analys av aktionsformer som bara flyktigt berör denna vidare rörelseproblematik är ofullständig eftersom den abstraherar från processer som måste ingå i ett vidare begrepp om klasskamp. Att dessutom inrikta analysen på en bestämd kategori av kollektivt handlande (arbetskonflikter) medför att viss klasskamp, som förs av grupper som ibland kallas "prekära", tenderar att utelämnas, inte minst då dessa grupper inte har utvecklat lika starka traditioner av arbetsplatskamp i Sverige som de har gjort annorstädes. Denna artikel är alltså med nödvändighet en partiell analys av klasskampen i Sverige.

Studien kompletterar och kompletteras av forskning om sociala rörelser. ${ }^{26}$ Där ingår en undersökning av en av modernitetens paradigmatiska aktionsformer - demonstrationen - samt en undersökning av hur protestcykler i spåren av den ekonomiska krisen 2007-2009 har interagerat med radikala politiska rörelser på vänsterkanten. ${ }^{27}$

Metodologiskt är min artikel besläktad med forskningen om sociala rörelser i den meningen att den utgår från antagandet att arbetskonflikter, som ett uttryck för proletär klasskamp, är en dynamisk praktik vars former ständigt förändras. Jag har i likhet med traditionell strejkforskning använt kvantitativa data för att konstruera tidsserier. Dessa data täcker dock mer än en aktionsform (kravaller, strejker och kollektiva uppsägningar), och för att koppla den generella analysen till maktresurser, strejkformer och framväxande proletära medvetandeformer har jag använt tidigare forskning samt den samlade erfarenheten från en kvalitativ studie av kollektiv uppsägning bland sjuksköterskor.

25. Schierup, Ålund \& Kings (2014). Se också Dahlstedt, Kings \& Tahvilzadeh (2018). 26. För en redogörelse för sociala rörelser i Sverige under efterkrigstiden, se Peterson, Thörn \& Wahlström (20I8).

27. Den förra finns i Wennerhag (2017); den senare i Wennerhag, Fröhlich \& Piotrowski (20I8). 


\section{Analys}

Jag behandlar i den här artikeln det frambrytande svenska strejkmönstret i fyra steg. I det första och andra steget undersöker jag ur ett internationellt perspektiv hur mönstret har förändrats historiskt samt kopplar dessa förändringar till förändringar i klasstrukturen. I det tredje steget utvecklar jag en typologi över samtida strejkformer efter vilka maktresurser arbetarna mobiliserar och vilka funktioner aktionerna således fyller. I det färde steget fokuserar jag på en bestämd aktionsform - den kollektiva uppsägningen - för att på mesonivå analysera de förändrade arbetsprocesser och medvetandeformer som är förbundna med enskilda aktioner.

\section{Strejkvågor}

För att få en känsla för vikten av att studera förändringar i klasskampens olikartade former är det givande att observera trender i större strejker och kravaller.

I diagram I ser vi, tvärtemot uppgifterna om att det totala antalet strejker skulle ha sjunkit, ett internationellt kampuppsving under senare år.

Diagram I. Kravaller och generalstrejker i I8 OECD-länder. Antal (som femairiga glidande medelvärden) 1946-20I5

Kravaller

Generalstrejker

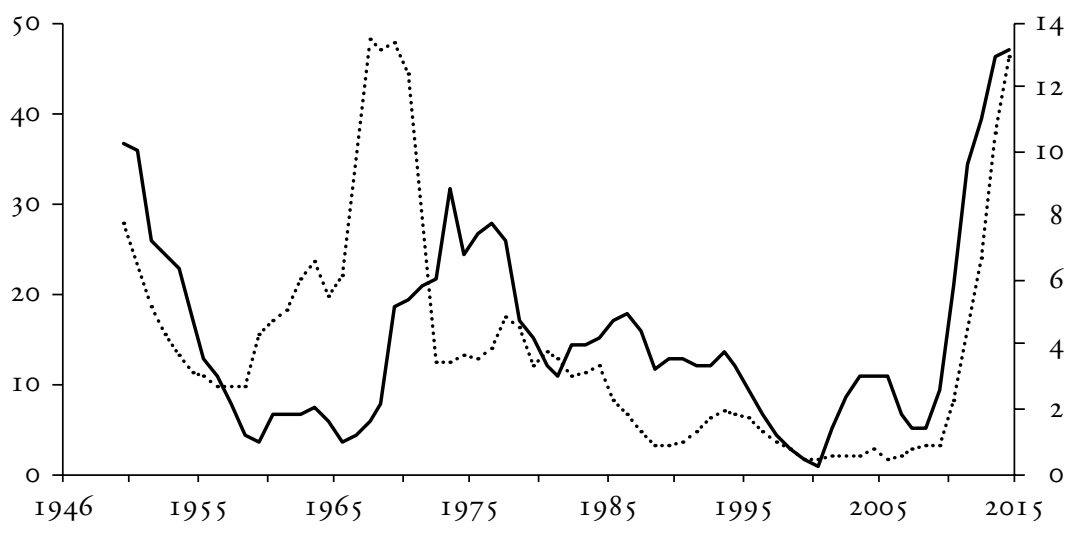

Källa: Uppgifter i "Cross-National Time-Series", https://www.cntsdata.com/. Se vidare Kelly (20I5), s. 727. 
Diagrammet fångar det sena 1960-talets uppgång (till exempel studentkravallerna och generalstrejken under den franska majrevolten 1968), liksom det uppsving som skett sedan 2010 (under 2010 till exempel den grekiska protestcykeln på våren och den franska mobiliseringen mot pensionsreformer efter sommaren). Långsiktiga trendbrott av detta slag brukar kallas "strejkvågor".

Studiet av strejkvågor har varit en källa till förnyelse inom strejkforskningen och har bland annat lett till ett fokus på hur olika aktionsformer utvecklas och avlöser varandra över tid. Dagens upplopp och kravaller har setts som uttryck för den sorts proletära tillvaro som utmärker den sentida kapitalismen, och den så kallade Occupyrörelsen har analyserats med utgångspunkt i dess släktskap med "kommunen" som en form varigenom spontan gatukamp stundtals erhåller stadga och en koordinerande kapacitet. ${ }^{28}$ Inom den traditionella strejkforskningen förde studiet av strejkvågor med sig ett fokus på hur olika grupper av arbetare under olika epoker går i bräschen för strejkrörelser. Skiften mellan sådana epoker utgör också skiften mellan kampformer, och dessa skiften speglar historiska förändringar i den allmänna klasstrukturen (makro) och i specifika arbetsprocesser (mikro). ${ }^{29}$

Långvågsperspektivet har ansetts vara ytterst tillämpligt på det svenska konfliktmönstret. Sett till strejkernas antal kan det senaste halvseklet i Sverige delas i två perioder: Den första perioden präglades av uppsvinget som började 1969 med strejkerna i Göteborgs hamn och Malmfälten. Under den senare perioden, från I99I, var strejknivån lika låg som under den tidiga efterkrigstidens gyllene år (det vill säga merparten av 1950och 1960-talet). Christer Thörnqvist menar att dessa svenska strejkvågor hänger ihop med långa vågor av tillväxt och kris. Efter en källkritisk diskussion om strejkstatistiken anmärker Thörnqvist:

Åtminstone en slutsats kan dras [...] Att det sena I9IO-talet och det tidiga 1970talet verkligen innebar kraftiga strejktoppar [...] Tillsammans med [strejkvågen I869-I874] får vi ett intressant mönster: Sverige stämmer perfekt in i [teorin om de långa vågornas betydelse]..$^{30}$

28. Clover (2016); Smith (20I4).

29. Kelly (1998); Mandel (1995); Screpanti (1987).

30. Thörnqvist (1994), s. 93. 
Även om svensk arbetsmarknad har sina egenheter finns det överensstämmelser mellan strejkutvecklingen här och i andra avancerade ekonomier, vilket avspeglar långvariga mönster i den globala kapitalackumulationen. Eftersom Thörnqvist beskriver en period på närmare I50 år står det klart att det inte är samma kategorier av lönearbetare som har gått i bräschen för strejkrörelserna. Under det sena I8oo-talet var det hantverksarbetare som ledde merparten av strejkerna; under 1930- och 1940-talet var det en industriarbetarklass i vardande; under 1970-talet var det nyckelgrupper i fordistisk industri (gruv-, stål- och bilindustrin). Det nuvarande strejkmönstret i avancerade ekonomier har betecknats som en "tertiarisering". ${ }^{\text {II }}$ Det vill säga att tjänste- och kommunikationsarbetare skulle vara vår tids avantgarde, något som också framträder vid en analys av det frambrytande svenska strejkmönstret.

Innan jag analyserar det samtida svenska strejkmönstret kan det vara klargörande att ge en mer utförlig beskrivning av de makrohistoriska perspektiv som har utvecklats inom komparativ forskning. Ett metodologiskt avgörande antagande är att det finns flera arbetarklasser. Beverly Silver visade i Forces of labor att nya omgångar av globalisering (det vill säga kapitalflykt undan arbetarkamp vid befintliga produktionsplatser) bidrar till att skapa nya - och i sinom tid militanta - arbetarklasser runt om i det globala syd. Silver visade att detta globala mönster samartikuleras med hur arbetarkamp migrerar inom länder och mellan sektorer. Det kompletterar och komplicerar det långvågsmönster som följer av pendlingarna mellan perioder av starkare och svagare ekonomisk tillväxt. Silver har också, liksom traditionella strejkforskare, noterat att arbetare inom kommunikations- och tjänstesektorn sedan 1970-talet står för en växande andel av den globala klasskampen. ${ }^{32}$

Silvers analys bidrar väsentligt till förståelsen av de egenskaper hos den nuvarande ackumulationsfasen som ger dagens klasskamp särskilda former. Under det sena 1960-talet hade en lång period av expansion i den "reala" (och i hög grad sysselsättningsskapande) ekonomin tryckt tillbaka arbetslösheten och därigenom stärkt arbetarna i förhållande till kapitalet. När så vinstnivåerna började falla och kriser åter gjorde sig gällande

3I. Bordogna \& Cella (2002).

32. Silver (2003), s. 98-99. 
svarade arbetare på försök att öka exploateringsgraden med lokala och ofta lyckosamma mobiliseringar.

I dag lyser dock omfattande lokal strejkaktivitet med sin frånvaro i avancerade ekonomier, trots kriserna efter 2007. Denna aktivitet kan enligt Silver i stället iakttas i det globala syd, i synnerhet i de geografiska områden som på senare år har varit skådeplatser för skapandet av nya arbetarklasser (under 20 Io utlöste strejkerna i Pärlflodsdeltat en nationell strejkvåg i Kina). Motståndet i Västeuropa och Nordamerika, där etablerade arbetarklasser under längre tid har försvagats och avvecklats, saknar i allmänhet en lokal dimension. I stället bemöts krismotiverad nedskärningspolitik med enskilda stora proteststrejker, mestadels utförda av offentliganställda, och med gatudemonstrationer och upplopp. En bakgrund till det är den tydligt finansiella karaktären hos den ekonomiska expansion som föregick den senaste krisen, vilken bidrog till att arbetslösheten, som hade börjat öka under 1970-talet, i hög grad bestod och därigenom försvagade äldre arbetarklasser i det globala nord. ${ }^{33}$

\section{Diagram 2. Antal strejker i Sverige I965-20I5}

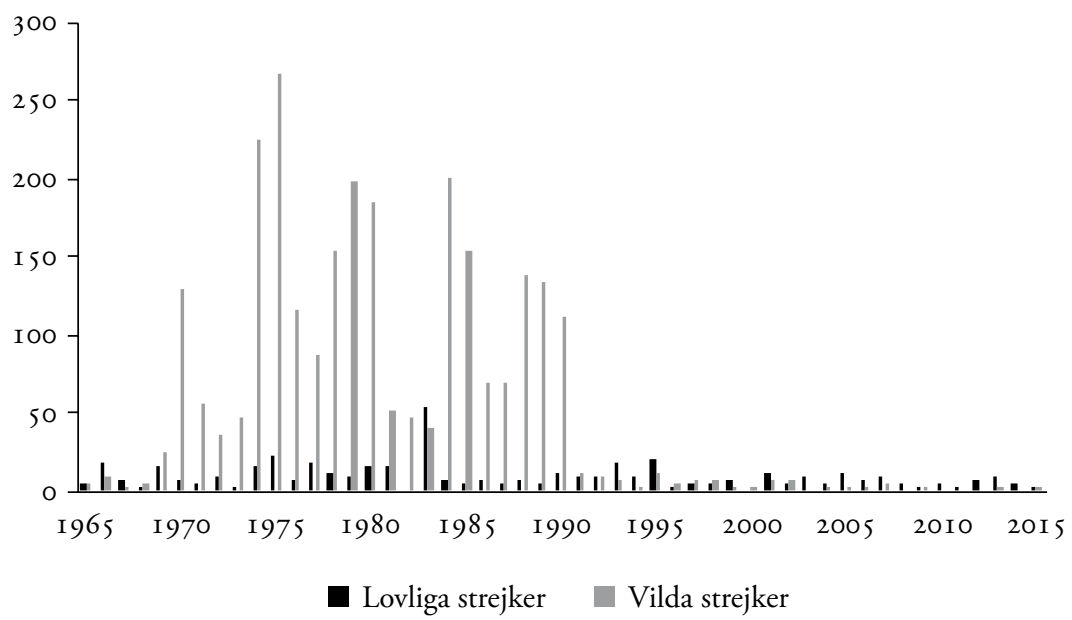

Källa: Uppgifter från Medlingsinstitutet, senaste sammanställningen finns på https:// www.mi.se/app/uploads/Konflikttabell_1965-2019.pdf (I8 november 2020).

33. Silver (2003), s. 163-167, I76. 
Diagram 2 visar att mönstret i Sverige både överenstämmer med och avviker från det internationella mönstret. Kollapsen för strejkrörelserna efter I990, som bör ses i ljuset av den kraftiga ökningen av arbetslöshet vid samma tid, innebar att Sverige något försenat inrättade sig i ledet. Statlig konjunkturpolitik och den offentliga sektorns expansion höll tillbaka en arbetslöshet som i stora delar av Västeuropa under 1980-talet hade undergrävt arbetarnas möjlighet att använda strejkvapnet. Men sedan 1990-talskrisen ligger antalet strejker i Sverige på en låg nivå. Vi har inte sett något kampuppsving efter 2007-2009 motsvarande det som ägt rum i andra länder. Å andra sidan går de huvudsakliga konturerna i det internationella uppsving som diagram I illustrerade att skönja också i Sverige.

Därutöver står klart att större konflikter på svensk arbetsmarknad tenderade att koncentreras till tjänstesektorn under 1980-talet och under årtiondets senare del särskilt till den offentliga sektorn, i linje med internationella trender. ${ }^{34}$ Ett iögonfallande särdrag är däremot dominansen av vilda strejker under 1970- och 1980-talen. Här skiljer sig Sverige dessutom från till exempel Storbritannien, som också såg flera inofficiella strejker vid denna tid men där lokala fackliga organisationer ändå spelade en viktig roll. I Sverige bidrog facklig centralisering och lagstiftning, inklusive lagen om kollektivavtal, till att blockera den lokala fackliga nivåns medverkan i inofficiella strejker.

\section{Strejkmönster och klasstruktur}

Förändringarna i strejkmönstret återspeglar förändringar i det svenska samhällets klasstruktur. Under efterkrigstidens första årtionden började viktiga förändringar i arbetarklassens sammansättning ske, även om klassens andel av de förvärvsarbetande förblev i det närmaste oförändrad. Således dominerades arbetarklassen under tidig efterkrigstid av arbetare inom olika former av tillverkningsindustri, och omkring 1980 var mer än hälften av klassen verksam inom tjänsteyrken. Därutöver hade olika mellanskikt vuxit, delvis på arbetarklassens bekostnad. Omkring 1980 identifierade klassforskare således gruppen "delvis självständiga lönearbetare", varav en betydande andel utövade professioner inom välfärdsstaten, som ett betydande skikt mellan arbete och kapital (I7 procent

34. Thörnqvist (1994), s. I28-I30. 
av de förvärvsarbetande). I en senare kommentar konstaterade Göran Ahrne, Hedvig Ekerwald och Håkon Leiulfsrud att ökningen av tjänsteyrkena i Sverige, och därigenom ökningen av de delvis självständiga, i hög grad kunde förklaras av den offentliga sektorns expansion. ${ }^{35}$

I dag är arbetarklassens andel av de förvärvsarbetande något lägre (ca 50 procent), men å andra sidan deklasseras eller proletariseras olika delvis självständiga mellanskiktsyrken. ${ }^{36}$

\section{Diagram 3. Antal strejkdagar i Sverige 1965-2015}

Lovliga strejker

— Vilda strejker

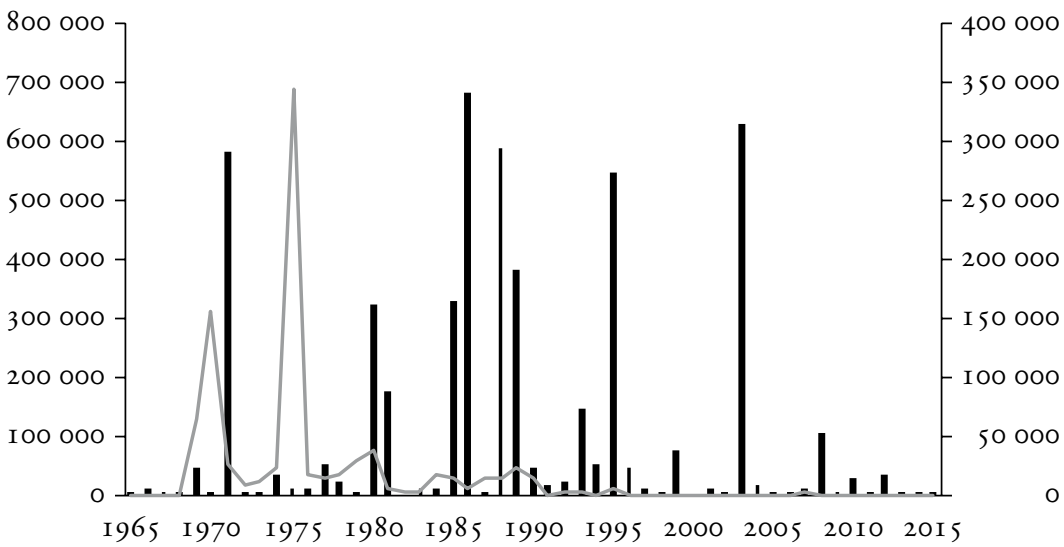

Källa: Uppgifter från Medlingsinstitutet, senaste sammanställningen finns på https:// www.mi.se/app/uploads/Konflikttabell_1965-2019.pdf (I8 november 2020).

Diagram 3 visar att större vilda strejker huvudsakligen ägde rum under tidigt 1970-tal (här väger gruv- och skogsarbetarstrejkerna tungt) och att lovliga strejker har dominerat sedan dess. Mätt i antalet strejker är trenden är inte lika tydlig; något motsvarande trendbrott skedde inte efter I980-talets slut. Omfattande enskilda konflikter fick antalet strejkdagar att tidvis skjuta i höjden även efter I990, särskilt åren 1995 och 2003 och i mindre utsträckning 1999 och 2008 (strejker genomförda av SHSTF [senare Vårdförbundet] och Kommunal bidrog kraftigt till dessa toppar).

35. Ahrne, Ekerwald \& Leiulfsrud (2018 [1995]), s. IV, 35-36, 40-43, 60-63. Jfr Ankarloo (1997).

36. Ahrne, Stöber \& Thaning (2018); Broström (2018). 
Den senaste tioårsperioden tycks ha varit fredlig, men det är ett åtminstone delvis bedrägligt intryck. Sett till större strejker präglades de första åren efter 1968 av de stora vilda strejkerna inom råvaruproduktion, transporter och tillverkningsindustri. Därefter följde en period när privata tjänstearbetare gick $\mathrm{i}$ bräschen, något som var särskilt tydligt $\mathrm{i}$ I980-talets början (med stora strejker av industritjänstemän, av banktjänstemän, och av tjänstearbetare inom PTK under 198I). I mitten av I980-talet blev den offentliga sektorn centrum för större konflikter, vilket fortfarande kan sägas vara fallet - med det viktiga tillägget att större konflikter numera allt oftare inbegriper logistiskt centrala arbetare som busschaufförer, piloter, lokförare, arbetare inom varutransport och handel samt nyckelgrupper i en alltmer integrerad och störningskänslig industri (till exempel elektriker). För dessa arbetare är ofta varsel om stridsåtgärd ett tillräckligt effektivt vapen, och öppna konflikter kan undvikas. Ett fåtal fackförbund inom transportsektorn stod för nästan en tredjedel av alla varsel på svensk arbetsmarknad 20II-20I5, och bara ett mindretal av dem verkställdes. ${ }^{37}$ Det minskade antalet strejkdagar under senare år ska alltså inte tas som belägg för att arbetarsidan är svagare i dag.

Vissa tidigare stridbara förbund har på senare tid anammat mer samarbetsinriktade strategier och delvis avhänt sig strejkvapnet. Avtalade begränsningar av konflikträtten i 1997 års industriavtal är ett exempel på detta. ${ }^{38}$ Det har lagt grunden för en konflikt mellan i synnerhet IF Metall å ena sidan och å andra sidan LO-förbund som gör mer aktivt bruk av konflikträtten.

Att större strejker koncentreras till offentliganställda och strategiskt placerade tjänsteproducerande arbetare, medan tillverkningsindustrin och råvarunäringarna står för en minskad andel av dessa konflikter, avspeglar de offentliga och privata tjänsteyrkenas växande andel av en brett definierad arbetarklass. Att de förstnämnda gruppernas fackföreningar anammar traditionella, konfliktbaserade fackliga strategier, medan det tidigare hegemoniska IF Metall har gått in för en samarbetsorienterad strategi och därigenom riskerar sin ledande ställning bland LO-förbunden, är förklarligt mot den bakgrunden.

37. Svenskt Näringsliv (20I6), s. I3; jfr Medlingsinstitutet (20I7), s. 96.

38. Angående 1997 års industriavtal, se Lundh (2002), s. 262-264; Nycander (2002), s. $4 \mathrm{I} 8-424$. 
Klasstrukturens förändringar och åtföljande förändringar i strejkmönstret kan också belysas ur ett komparativt perspektiv utifrån det metodologiska antagandet om att det finns flera arbetarklasser. Silver pekade i Forces of labor på att klasskamp speglar arbetarklasser på frammarsch såväl som på tillbakagång. Välfärdsarbetare och logistiskt centrala arbetare, som alltså står för en växande andel av de större strejkerna i Sverige, är mestadels att betrakta som arbetarklasser som har skapats på senare tid till följd av tjänsteyrkenas proletarisering (bland annat inom vården) och tillkomsten av nya proletära aktörer (alternativt att befintliga grupper, exempelvis elektriker, har stärkt sin maktposition i en mer störningskänslig ekonomi). Det förs också en kamp bland äldre arbetarklasser som i dag är på tillbakagång för att försvara tidigare landvinningar och arbetsvillkor; ett uttryck för det var protesterna 2009 i samband med krisen i den svenska fordonsindustrin.

Silver har reviderat sin analys och inkluderat ett tredje kampscenario där grupper, framför allt i det globala syd men också i avancerade ekonomiers förorter och glesbygd, blir överflödiga och stöts ut ur den internationaliserade kapitalackumulationen. Tillsammans med de nya och de äldre arbetarklasserna bildar de det samtida internationella kampuppsvingets anatomi. ${ }^{39}$

Att vara överflödig hänger nära samman med det numera ofta uppmärksammade tillståndet att vara "prekär". Dessa gruppers kamp har kommit till uttryck bland annat i de upplopp som sedan 2010 utbrutit i metropoler som London, Paris och Aten, och som 2013 nådde Sverige i och med de händelser som började i Husby. I detta sammanhang vill jag också nämna den organisering som pågår med utgångspunkt i de större svenska städernas förorter. ${ }^{40}$

\section{Strejkformer}

Frånvaron av stora strejker på senare år bör inte tas som intäkt för svensk arbetsmarknads så omtalade fredlighet. Däremot kan vi mot bakgrund av sentida större strejker urskilja två tendenser inom den övergripande trenden mot klasskampens tertiarisering: å ena sidan "logistikstrejker" och å andra sidan "välfärdsstrejker", vilka - för att återkoppla till de

39. Silver (20I3); Silver \& Karataşlı (20I5). Se också Karataşlı m.fl. (20I5).

40. Kings (2014). 
förändringar i klasstrukturen som jag nämnde i början av föregående analysavsnitt - svarar mot två tendenser inom den vidare trenden mot klassamhällets tjänstefiering. Arbetarklassens sammansättning har förändrats så att andelen industriarbetare har minskat till förmån för arbetare inom varucirkulation och transport (det vill säga handel och kommunikation) och olika professioner (inte minst inom offentlig sektor).

De strejker inom tillverkningsindustri och råvaruutvinning som under 1970-talet utmanade etablerade konfigurationer av kapitalmakt och byråkratiska fackliga strukturer, hämtade sina maktresurser ur det faktum att det fanns nyckelgrupper vid dessa arbetsplatser som genom att vägra arbeta kunde få hela kedjan av produktionsprocesser att avstanna. Den "flödesproduktion" som utmärker fordismen har i dag generaliserats bortom den individuella arbetsplatsen eller koncernen och inbegriper flera sammanlänkade värdekedjor. På samma sätt som nyckelgrupperna var utgångspunkten för 1970-talets arbetarmakt finns i dag logistiska knutpunkter eller noder samt stora koncentrationer av logistikarbetare vid dessa noder. ${ }^{4 \mathrm{I}}$

Logistiska strejker får sin kraft av förmågan att bryta vidsträckta flöden av varor, inklusive varan arbetskraft, som inkluderar flera arbetsplatser och företag. De slår inte direkt mot värdeproduktionen utan snarare mot värdets realisering. De utnyttjar produktionens branschövergripande socialisering (för att använda Marx’ terminologi) och den störningskänsliga synkroniseringen av varuflöden; flöden av varor som dagens kapitalism strävar efter att leverera just-in-time. ${ }^{42}$ Ett annat sätt att uttrycka det är att logistiska strejker slår mot cirkulationen av varor.

Här bör också noteras att lockouter under de senaste tjugo åren har genomgått en markant nedgång. Det finns anledning att anta att faktorer som stärker arbetare i branscher som är uppbyggda kring komplicerade och vidsträckta värdekedjor på ett motsvarande sätt avskräcker företag

4I. Moody (20I7). En ytterligare maktresurs för arbetare inom dessa logistiska kluster är logistikföretagens numera höga kapitalintensitet och medföljande sårbarhet.

42. För reflektioner kring dessa teman, se Toscano (20I4). Ett svenskt exempel på logistikstrejker - utöver en rad strejker på transportområdet - är lagerarbetarnas strejk på Lagena 2009, se Tuuloskorpi (2015), s. 97-II7. Strejken 1997 inom United Parcel Service uppmärksammades just för hur den synliggjorde arbetares maktresurser i en just-in-timestyrd ekonomi. Se Coleman \& Jennings (1998). 
från att vidta konfliktåtgärder. De allt högljuddare kraven på inskränkningar i konflikträtten har här en av sina orsaker. ${ }^{43}$

Välfärdsstrejkerna förefaller väsensskilda från de fordistiska och logistiska strejkerna. Medan de senare direkt och indirekt slår mot produktionen och realiseringen av mervärde orsakar välfärdsstrejkerna, särskilt i länder som Sverige, där dessa tjänster utförs inom offentlig sektor, vanligen inte stora inkomstbortfall. I litteraturen framhävs i stället den mobiliserande effekt dessa strejker kan ha när de artikuleras som ett försvar av sociala rättigheter (det vill säga som allmänintresse). "Våra arbetsvillkor är elevernas studievillkor", skanderar lärare i USA. Aktioner av detta slag mobiliserar ett socialt etos och övergår på så sätt i expansiva rörelser som universaliserar strejkkrav, söker publicitet och politiserar allt fler samhällsområden, fjärran från den arketypiska partikulära strejken som rör specifika gruppers arbetsvillkor utan att knyta dem till någon övergripande social problematik. ${ }^{44}$

Tabell I. Strejktypologi

\begin{tabular}{|l|l|l|c|c|c|}
\hline Strejktyp & Funktion & Klassposition & $\begin{array}{c}\text { Fram- } \\
\text { brytande }\end{array}$ & $\begin{array}{c}\text { Generali- } \\
\text { serande }\end{array}$ & $\begin{array}{c}\text { Arbetar- } \\
\text { kontroll }\end{array}$ \\
\hline $\begin{array}{l}\text { Fordistisk } \\
\text { strejk }\end{array}$ & $\begin{array}{l}\text { Stoppar värde- } \\
\text { produktionen }\end{array}$ & Proletär & $\checkmark$ \\
\hline $\begin{array}{l}\text { Logistik- } \\
\text { strejk }\end{array}$ & $\begin{array}{l}\text { Bryter } \\
\text { värdekedjor }\end{array}$ & $\begin{array}{l}\text { Proletär/delvis } \\
\text { självständig }\end{array}$ & $\checkmark$ & $\checkmark$ & \\
\hline $\begin{array}{l}\text { Välfärds- } \\
\text { strejk }\end{array}$ & $\begin{array}{l}\text { Artikulerar } \\
\text { allmänintresse }\end{array}$ & $\begin{array}{l}\text { Delvis } \\
\text { självständig }\end{array}$ & $\checkmark$ & $\checkmark$ & \\
\hline
\end{tabular}

Det kan vara belysande att stanna upp och reflektera över den allmänna riktningen hos frambrytande strejkformer. En sådan riktning blir tydlig först i ett scenario där strejkkampens skala kraftigt och hastigt expanderar. Referenspunkter hämtas därför lämpligen från det globala klasskampsuppsvinget efter 1968. Det är också i jämförelse med 1970-talets

43. Kjellberg (200I), s. 251, 262-264.

44. Ancelovici (2OII). Se också Brenner (20I4). 
vilda strejker som de historiska förändringarna i det svenska strejkmönstret tydligast framträder.

Sett till den allmänna riktningen hos strejker under 1970-talet, och särskilt de strejker jag har kallat fordistiska, var ett utmärkande drag, när de generaliserades, att de ibland direkt utmanade kapitalmakten på strejkdrabbade arbetsplatser, och i en vidare bemärkelse aktualiserade frågan om arbetarkontroll. ${ }^{45}$ Ett kvantitativt fokus har förpassat denna fråga till periferin av svensk strejkforskning, men ett internationellt sett utmärkande drag för svenska 1970-talsstrejker är att de aktualiserade frågan om makten över arbetet trots att landet inte såg någon direkt revolutionär situation (som i till exempel Frankrike och Portugal). Ett övergripande skäl till det står att finna i att etablerade fackliga organisationer inte kunde ta ledningen i vilda strejker. Detta vakuum fylldes av en spontan rådsdemokratisk strejkorganisation, en organisationsform som förkroppsligade, förebådade och symboliserade alternativa produktionsförhållanden, och som ibland överlevde själva arbetskonflikterna och innebar en mer långvarig utmaning av kapitalmakten. En annan orsak till striderna om kontrollen över arbetet var kvardröjandet av hantverksmässiga inslag av arbetarkontroll och självstyre inom råvaruutvinning och tillverkningsindustri. ${ }^{46}$ När dessa inslag utmanades av tendenser mot reell underordning politiserades kontrollfrågan.

Fordistiska strejker var lokala tilldragelser på så sätt att de - även när en strejkkampanj gällde flertalet arbetsplatser - utgick från arbetares förmåga att direkt stoppa produktionen vid enskilda arbetsplatser och utifrån den positionen genomdriva strejkkrav (vilket fortfarande är framkomligt på sina håll). I jämförelse med logistik- och välfärdsstrejker framstår därför det fordistiska strejkmönstret som ett myller av relativt isolerade konfliktpunkter. Därmed inte sagt att länkar saknades mellan konflikter av detta slag, men när sådana uppstod (genom den så kallade stridsfonden eller konferenser med arbetare som ledde vilda strejker, till exempel) markerade dessa inte sällan en organisatorisk innovation från arbetarhåll; alternativt var sådana länkar del av en centraliserad facklig

45. Mandel (I97I); Bayat (I99I); Ness \& Azzellini (20II). För en analys av frågan om arbetarkontroll i svenska strejkrörelser, se Granberg (2OI2).

46. Svensson (1984). 
strategi där arbetare vid flertalet arbetsplatser togs ut i strejk. Kontrasten mellan dessa mönster orsakas inte främst av en ökad sammanlänkning av ekonomiska och sociala aktiviteter - en stapelvara i sociologiska narrativ om senmodernitet - utan av att kapitalackumulationen i dag kräver synkroniserade varuflöden. Det gör logistiska noder till potentiella slagfält (choke points) där utfallet i en lokal kamp avgör hur en mer vidsträckt rörelse utvecklas. Rörelsen har därmed intresse av att understödja den lokala kampen. Den senare är i en väsentlig mening, för att låna en term från Dorothy Smith, "extralokal" (något som även kan sägas om välfärdsstrejker). Sverige har inte sett en renodlad "proxystrejk" av detta slag ännu, men exempel inkluderar blockaden av oljeraffinaderier under protesterna mot pensionsreformer i Frankrike 20I0. ${ }^{47}$

I tabell I sammanfattas de tre diskuterade strejkformerna. Indelningen är baserad på strejkernas olikartade funktioner, alltså hur de mobiliserar olika maktresurser för att pressa motparten. I stora drag går det också att urskilja skillnader i klassposition hos arbetare som vidtar de olika strejkformerna. Fordistiska strejker präglade den andra halvan av 1900-talet medan de två andra formerna har slagit igenom på senare tid (de är med andra ord frambrytande). Det ska dock återigen betonas att det rör sig om en hög grad av överlappning och samartikulering.

Logistik- och välfärdsstrejkerna har det gemensamt att deras funktion är generaliserande. Deras effekter begränsar sig inte till den omedelbara arbetsköparen (ett företag som agerar inom offentligt reglerad transportverksamhet, ett lokalt landsting, etcetera) utan påverkar den ekonomiska och politiska omgivningen i stort. De innebär därför potentiellt en konflikt med staten i vid bemärkelse. I logistikstrejkernas fall beror det på att effekterna av avbrott i centrala värdekedjor kan vara så omfattande att stater väljer att intervenera (något som i varje fall åberopades under de senaste konflikterna i Göteborgs hamn). Dessa strejker kan också avbryta cirkulationen av varan arbetskraft, vilket kan politisera frågor rörande kollektivtrafikens förutsättningar och sociala funktioner. Välfärdsstrejker, i sin tur, är ytterst en kritik av politiska beslut gällande välfärdsverksamheternas finansiering och organisering.

47. Badiou (2012). s. 29-30. 


\section{Arbetsprocesser och medvetandeformer}

I detta avsnitt fokuserar jag på förändringar i klasstrukturen för att belysa samspelet mellan förändringar i arbetsprocesser, medvetandeformer och kampformer. Den reella underordningen av cirkulationsarbetare och av offentliga professioner har skapat arbetsvillkor som underblåser utvecklingen av traditioner av klasskamp bland dessa grupper. Jag kommer att illustrera detta med sjuksköterskornas kollektiva uppsägningar.

I tidigare analysdelar undersökte jag hur förändringar i arbetarklassens sammansättning medfört förändrade konfliktmönster på svensk arbetsmarknad. Besläktade förändringar som berör mellanskikten är proletarisering och reell underordning. Det gäller särskilt de välfärdsarbetare som i slutet av 1900-talet beskrevs som "delvis självständiga" av svenska klassforskare. Dessa arbetare är i dag relativt benägna att genomföra lokala och informella konfliktaktioner.

De proletariseringsprocesser som nu präglar välfärdsarbetena kan förstås som en underminering av professionell autonomi orsakad av reell underordning, av tekniska och organisatoriska förändringar i arbetsprocessen som avlägsnar självstyrets förutsättningar. Men reell underordning är inte ett fullbordat tillstånd utan snarare en tendens inom en vidare förändringsprocess, vars utgång är oviss och därmed präglad av kamp. Mot bakgrund av dessa förändringar växer strejkrörelser bland välfärdsarbetare fram. ${ }^{48}$

Välfärdsarbetarnas reella underordning kan ses som ett bärande inslag i den vidare omstrukturering av offentlig sektor och statens förändrade förhållande till privat kapitalackumulation som har kallats nyliberalism. Den nyliberala statens strävanden att skapa förutsättningar för vidsträckta värdekedjor och varufiera offentliga tjänster är en orsak till det mönster av logistik- och välfärdsstrejker som vi har sett. ${ }^{49}$ Varufieringen av välfärdstjänster och den reella underordningen av välfärdsarbetare har ofta

48. Granberg (20I6). En viktig studie som i Marx efterföljd kopplade strejker till kontroll över arbetsprocessen och förändringar i arbetsorganisationen är Montgomery (1979). 49. Här tangeras paradoxen att nyliberalismen, som ofta ses som en decentrering av staten, i realiteten fordrar en handlingskraftig stat som skapar arenor för kapitalackumulation; se Foucault (2013). Det är en stat genomsyrad av kapitalformer, predisponerad att införa dessa former på alla samhällsområden. För marxistisk statsteori i denna anda, se O’Kane (20I4). 
skett under rubriken new public management (NPM; liksom gruvarbetarna gick till storms mot UMS har välfärdsarbetaren av i dag sin egen antagonistakronym). En tydligare bild av dessa dynamiker framträder dock först när man tittar närmare på enskilda verksamheter, professioner och specialister. Först då blir det tydligt hur förändrade arbetsprocesser och medvetandeformer påverkar framväxten av nya kampformer.

En grupp välfärdsarbetare har utmärkt sig vad gäller att genomföra lokalt baserade former av kollektivt handlande i Sverige: sjuksköterskorna. De har sedan sent 1980-tal med viss regelbundenhet vidtagit en åtgärd som pressen ofta kallat "massuppsägning": hotat att säga upp sig kollektivt om arbetsköparen inte gör vissa medgivanden (ofta framlagt av merparten sjuksköterskor på exempelvis en sjukhusavdelning).

Bakgrunden till aktionerna är, utöver omedelbara krav på till exempel högre löner eller bättre bemanning, den utveckling mot reell underordning och varufiering som gjorde entré i Sverige med nyliberalismen under sent 1980-tal och fick sitt verkliga genombrott i samband med 1990-talskrisen. ${ }^{\circ 0}$ Sjuksköterskearbetets reella underordning yttrar sig bland annat i mindre tid till fortbildning, reflektion och planering, och därigenom minskade möjligheter att tillämpa professionell kunskap; i ett uppdrivet arbetstempo samt i ökad detaljstyrning (genom till exempel kodsystem och så kallade kliniska protokoll). Kort sagt utmanas det professionella självstyret. Initiativet i arbetet och därmed makten över dess rytm ligger ofta inte längre hos sjuksköterskor och andra professionella inom sjukvården utan ibland snarast i arbetsprocessens egna immanenta logik. Interna prissättningssystem (en begynnande varufiering av sjukvårdstjänster) utgör en automatiserad form av styrning.

Men tendenserna mot reell underordning och dess effekt på maktförhållanden är motsägelsefulla. Således visar intervjuer med sjuksköterskor som genomfört kollektiva uppsägningar att medan dessa tendenser

50. Granberg (2016); Strömberg (2004); Andersson-Skog \& Strömberg (2012). Två belysande fallstudier här är Selberg (20I2) och Rankin \& Campbell (2009). Tendenser till reell underordning är inte nödvändigtvis liktydigt med en utarmning av arbetets kunskapsinnehåll, därmed inte heller nödvändigtvis med en försvagning av arbetarnas förhandlingsposition, även om så ofta varit fallet. Standardisering har inte undergrävt vårdprofessionernas maktposition, trots att arbetsprocessernas utformning och tempo i ökad utsträckning styrs av en abstrakt vårdapparat och inte av professionerna själva. 
bidrar till känslor av maktlöshet och hotar det professionella självstyret medför de samtidigt en tudelning mellan "vi på golvet" och en opersonlig och abstrakt "ledning", vilket skapar subjektiva förutsättningar för kollektiva aktioner. Här framgår det att NPM, utöver en objektiv deklassering av mellanskiktens arbetsvillkor, också bidrar till framväxten av ett klassmedvetande bland vissa yrkesgrupper (och omvänt: en äldre professionell organisation präglad av "kollegialitet" bidrog tidigare till att blockera sådant medvetande). ${ }^{\text {II }}$ Tendenserna innebär också att vissa sjuksköterskor stärker sin position gentemot arbetsköparen. Ett växande behov av utbildad och erfaren personal i en specialiserad och teknologiskt avancerad sjukvård, i kombination med sjuksköterskebrist orsakad av årtionden av besparingar, innebär att särskilt specialistsjuksköterskor har stärkt sin förhandlingsposition i kontrast till arbetsvillkorens försämring (inte minst vad gäller arbetstider och -tempo).

Ur ett klasstrukturperspektiv är förändringarna av sjuksköterskornas arbete att betrakta som förändringar på mesonivå. De belyser proletariseringen av ett delvis självständigt mellanskikt både i objektiv mening (arbetsprocessernas förändring) och fenomenologisk mening (hur relationen till arbetsköparen upplevs).

En viktig historisk lärdom är att reell underordning, även om den först verkar avlägsna grunden för arbetarmakt, ofta har motsatt effekt på längre sikt. När äldre produktionsformer inom tillverkningsindustrin försvann i mitten av 1900-talet blev tidigare stridbara hantverkare till synes maktlösa. Men omvandlingen skulle leda till den fordistiska strejkform som blev sinnebilden för arbetarkamp. Sjuksköterskornas nuvarande situation är snarlik.

Två sorters processer stärker sjuksköterskorna i förhållande till arbetsköparna: de som minskar tillgången på arbetskraft och de som gör arbetsköparen finansiellt sårbar när denna arbetskraft undandras. Ett globalt underskott på sjuksköterskor präglar den nyliberala sjukvården, och i Sveriges fall drabbade dessutom 1990-talets nedskärningar i första hand grupper som läkarsekreterare och undersköterskor, vilket innebar att efterfrågan på sjuksköterskor snarast växte. ${ }^{52}$ Därtill kommer vår närhet till Norge och de goda arbetsvillkor som erbjuds sjuksköterskor där.

5I. Jfr Broström (2018).

52. Selberg (2012), s. II9. 
Mindre uppenbart är det kanske hur nyliberalismen - särskilt genom varufiering - har ökat arbetsköparens finansiella sårbarhet.

Att sjuksköterskors maktposition har stärkts under nyliberalismen framgår av diagram 4. Mellan 1985 och 2015 stod sjuksköterskor årligen för i genomsnitt cirka hälften av de kollektiva uppsägningarna på den svenska arbetsmarknaden. Andra grupper som vidtog denna kampform var bland annat socialarbetare, brandmän, läkare och poliser.

I en genomsnittlig kollektiv uppsägning bland sjuksköterskor hotar I7 anställda med att säga upp sig. Liksom för vilda strejker gäller att kollektiva uppsägningar överlag är lokala, arbetsplatsbaserade aktioner. I 70 procent av fallen arbetar sjuksköterskorna på arbetsplatser där specialistutbildning fordras. Det är också dessa sjuksköterskor (inom exempelvis intensivvård, kirurgi och akutsjukvård) som tenderar att gå segrande ur maktkampen. I hälften av fallen drog sjuksköterskorna tillbaka sina uppsägningar efter att arbetsköparen gjort eftergifter, varav merparten på arbetsplatser som fordrar specialistutbildning. Sjuksköterskor vid avdelningar som utför region- eller riksuppdrag, vilket ger avdelningarna karaktär av "kassakor" (ett uttryck som återkom i intervjuer med sjuksköterskor som deltagit i kollektiva uppsägningar), verkar särskilt kapabla att tvinga motparten till eftergifter. ${ }^{53}$

\section{Diagram 4. Antal kollektiva uppsägningar genomförda av sjuksköterskor i Sverige 1985-2015}

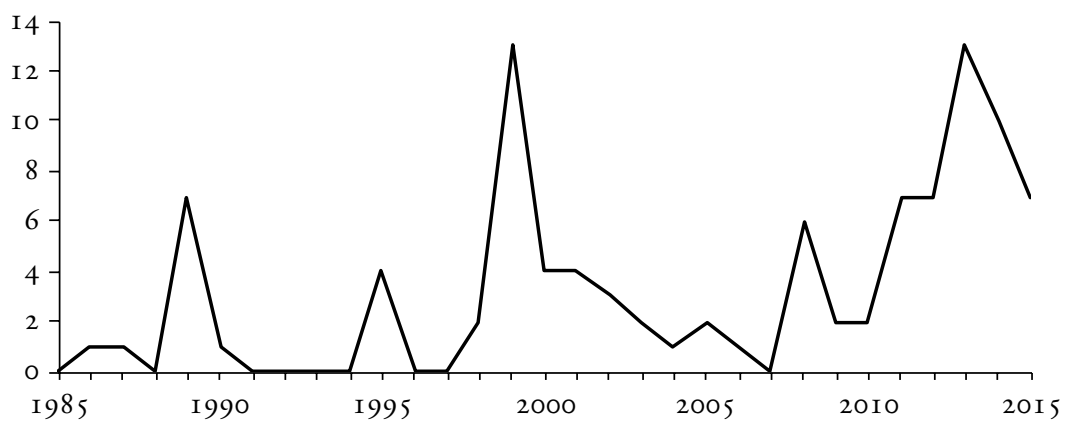

Källa: Mediedatabasen Retriever. Se Granberg (2017).

53. För en mer ingående analys av varufieringens betydelse vid kollektiva uppsägningar, se Granberg (2017). 
Diagram 4 visar att informell kamp har varit ett nödvändigt men sällan erkänt komplement till officiella arbetsmarknadsinstitutioner. Liksom vilda strejker har kollektiva uppsägningar bland sjuksköterskor tenderat att äga rum i nära anslutning till tecknandet av kollektivavtal. Vid slutet av 1980-talet inleddes en rörelse mot lokala förhandlingar och individuella löner, och de centrala avtalsförhandlingarna 1988 följdes av en första våg av kollektiva uppsägningar. Likaså präglades förhandlingarna i slutet av I990-talet av lokala avtalsstrider.

Den fackliga organisation som senare skulle bli Vårdförbundet uppmuntrade kollektiva uppsägningar under sent 1980-tal, men var närmast fientligt inställt till dessa aktioner när avtal skulle tecknas tio år senare. En sådan ambivalent attityd till lokal aktivism känns igen från de vilda strejkerna och var kanske som mest påtaglig när ett nationellt upprop för massuppsägning bidrog till att pressa fackförbundet ut i strejken 2008.

I stället för ett abrupt produktionsstopp, som vid en vild strejk, ger den kollektiva uppsägningen arbetsköparen respit att hantera sjuksköterskornas missnöje. I kollektiva uppsägningar används det verktyg vi numera kallar strejk på ett sätt som känns igen från arbetarrörelsernas begynnelse - ett strategiskt bruk av uppsägning som gick i graven med konflikternas institutionalisering i samband med Saltsjöbadsavtalet men som nu återuppstått i informell skepnad. ${ }^{54}$

Kollektiv uppsägning lägger ansvaret för att hålla igång verksamheten på arbetsköparen, vilket gör att sjuksköterskorna kan mobilisera ett välfärdsetos och därigenom, som strejkforskaren Linda Briskin har betonat, politisera frågor om vård och omvårdnad samtidigt som etablerade konfigurationer av femininitet och kapitalmakt destabiliseras. ${ }^{55}$ Detta bildar en reproduktiv maktresurs som ligger till grund för välfärdsstrejken.

Som vi har sett visar dock en närmare analys av de svenska sjuksköterskornas aktioner att detta drag hos välfärdsstrejken, på grund av förändringar i klasstrukturens mikronivå (det vill säga på arbetsprocessnivå), kombineras med maktresurser som uppstår inom ett komplext nätverk av varufierade vårdtjänster - maktresurser som generellt sett är utmärkande för de fordistiska och logistiska strejkerna.

54. Karlbom (1967), s. 247; Bengtsson (2006).

55. Briskin (2013), s. I05-I34. 


\section{Slutsatser}

Det samtida uppsvinget i klasskampen tycks ha två aspekter. Den första, som jag inte har gått närmare in på här, inkluderar vad Alain Badiou har beskrivit som "en tid av upplopp". ${ }^{66}$ Den framträdde efter krisen 2007-2009 och där ingår "rörelsen på torgen" och "de prekära”. Den andra aspekten är de arbetarrörelser vars kärntrupper är välfärdsarbetare, samt de offentlig- och privatanställda vars strejker vållar logistiska sammanbrott.

Denna aspekt av uppsvinget uttrycker långvariga historiska tendenser och är inte lika iögonfallande som den första, och den fördunklas av narrativen om hur klass tynar bort. Sådana arbetarrörelser kan dock komma att ha betydelse framöver, liksom arbetarkampen hade under uppsvinget efter 1968. Något som talar för det är statens centrala roll under nyliberalismen, särskilt under kriser, när statens roll som marknadens garant accentueras samtidigt som den blir en arena för kamp. Situationen tillspetsas av långsiktiga förändringar i klasstrukturen - reell underordning och varufiering - som proletariserar tjänsteyrkena. Ännu tycks dock inte dessa strukturella förändringar motivera tjänstearbetare att utmana kapitalförhållandet, såsom reell underordning tidigare politiserade frågan om makten över arbetet inom industrin.

Medan gamla arbetarklasser försvagas växer nya arbetarklasser fram. Det sker parallellt med utvecklingen av nya kampformer. Att tillämpa en enhetlig standard i analyser av arbetskonflikt, som den positivistiskt inriktade strejkforskningen ofta har gjort, kan dock osynliggöra de nya, emergenta kampformerna. Med det marxistiska långtidsperspektiv som jag har anlagt här har jag velat lyfta fram dem. Därmed har jag negligerat vissa traditionella kampformer, men å andra sidan kan den strejktypologi som jag har utvecklat visa att element av I900-talets emblematiska strejker lever vidare som aspekter av frambrytande kampformer: I logistikstrejker har potentialen att stoppa värdeproduktionen som utmärkte fordismens arbetsplatsbaserade strejker vidgats till kedjor av varucirkulation och -produktion som innefattar flera arbetsplatser och företag. Välfärdsstrejker och gräsrotsaktioner visar att nya maktresurser gör att arbetare

56. Badiou (20I2), s. 5. 
numera kan hota arbetsköpare finansiellt, resurser som ironiskt nog tillskänktes arbetarna av de nyliberala reformister som skulle konsolidera kapitalmakten.

Dessa maktresurser, som illustreras tydligast i sjuksköterskornas kollektiva aktioner, är att betrakta som baksidan av den varufiering som präglar nyliberala stater. I och med denna förändring omkastas ett av de grundläggande förhållanden som historiskt sett bidragit till att offentliganställda inte har kunnat utmana arbetsköparna lika effektivt som till exempel industriarbetare: de producerade inte varor, och deras förmåga att åsamka arbetsköpare finansiell skada var därmed begränsad.

Proletarisering och reell underordning bidrar å sin sida till att skapa den klyfta mellan arbetare och ledning som är en subjektiv förutsättning för arbetarkamp. På ett analogt sätt verkar trenden mot allt tydligare knutpunkter i kapitalets kretslopp skapa förutsättningar för effektiva aktioner, trots att en tidig effekt av den globalisering och tekniska rationalisering som dessa trender avspeglar var att försvaga etablerade arbetarklasser, särskilt inom tillverkningsindustrin i det globala nord.

Framtida rörelser bland välfärdsarbetare och strategiskt placerade logistikarbetare är beroende av hur de pågående förändringarna i klassstrukturen och dess arbetsprocesser påverkar dessa arbetares maktposition, samt av huruvida arbetarna kan utveckla de beständiga organisationer, de traditioner av kamp och det klassmedvetande som behövs för att ta rörelserna till nya nivåer. Konkret skulle detta i första hand kunna inbegripa proxystrejker, såsom vi har sett i mer konfliktintensiva länder. 


\section{Referenser}

Ahrne, Göran, Hedvig Ekerwald \& Håkon Leiulfsrud (2018 [1995]) Klassambällets förändring. Lund: Arkiv förlag. DOI: https://doi.org/IO.I3068/9789179243265

Ahrne, Göran, Niels Stöber \& Max Thaning (2018) Klasstrukturen i Sverige. Struktur, klass och inkomster: kontinuitet och förändring 1985-20I5. Rapport från Katalys. URL: https://www.katalys.org/wp-content/uploads/20I8/06/No-20.-Klasstruktureni-Sverige.pdf (I8 november 2020)

Ancelovici, Marcos (20II) "In search of lost radicalism: The hot autumn of 2010 and the transformation of labor contention in France", i French Politics, Culture \& Society volym 29, nr 3, s. I29-I40.

DOI: https://doi.org/I0.3167/fpcs.20II.290308

Andersson-Skog, Lena \& Helén Strömberg (red.) (20I2) Från en öm hand till kall elektronik? Om industrisambällets vårdarbete under Igoo-talet. Umeå: Umeå universitet.

Ankarloo, Daniel (1997) "Farväl till arbetarklassen?", i Motströms nr I.

Badiou, Alain (2012) The rebirth of history. Times of riots and uprisings. London: Verso.

Bayat, Assef (199I) Work, politics and power. An international perspective on workers' control and self-management. New York: Monthly Review Press.

Bengtsson, Berit (2006) Kampen mot $\$ 23$. Facklig makt vid anställning och avsked $i$ Sverige forr 1940. Uppsala: Uppsala universitet.

Bordogna, Lorenzo \& Gian Primo Cella (2002) "Decline or transformation? Change in industrial conflict and its challenges", i Transfer: European Review of Labour and Research volym 8, nr 4, s. 585-607. DOI: https://doi.org/IO.II77/I0242589020080040I

Brenner, Aaron, Robert Brenner \& Cal Winslow (red.) (2010) Rebel rank and file. Labor militancy and revolt from below in the long 1970s. London: Verso.

Brenner, Johanna (20I4) "2Ist century socialist-feminism", i Socialist Studies volym Io, nr I, s. 3I-49. DoI: https://doi.org/I0.18740/S4RP 43

Briskin, Linda (2013) "Nurse militancy and strike action", i Workers of the World: International Journal on Strikes and Social Conflict volym I, nr 2, s. IO5-I34. URL: https://workersoftheworldjournal.files.wordpress.com/20I4/Io/workers-ofthe-world_-international-journal-on-strikes-and-social-volume-I-number-2I.pdf (I8 november 2020)

Broström, Lovisa (2018) Medelklassens förändrade maktposition. Deklasseringen av lärare, poliser och sjuksköterskor, samt nya klasskonflikter inom medelklassen. Rapport från Katalys.

URL: https://www.katalys.org/wp-content/uploads/2018/03/No-I2.-Medelklassensf\% 3 $3 \% \mathrm{~B} 6 \mathrm{r} \% \mathrm{C}_{3} \% \mathrm{~A} 4$ ndrade-maktposition.pdf ( 18 november 2020)

Brown, Henry Phelps (1990) "The counter-revolution of our time", i Industrial Relations: A Journal of Economy and Society volym 29, nr I, s. I-I4. DoI: https://doi.org/Io.IIII/j.I468-232X.199o.tboo738.x 
Carchedi, Guglielmo (1987) Class analysis and social research. Oxford: Basil Blackwell.

Clover, Joshua (2016) Riot. Strike. Riot. The new era of uprisings. London: Verso.

Coleman, Jay \& Kenneth Jennings (1998) "The UPS Strike: Lessons for just-in-timers", i Production and Inventory Management Journal volym 39, $\mathrm{nr}$ 4, s. 63-67.

Crouch, Colin \& Alessandro Pizzorno (red.) (1978) The resurgence of class conflict in Western Europe since 1968. London: Macmillan.

Dahlstedt, Magnus, Lisa Kings \& Nazem Tahvilzadeh (red.) (2018) Platskamp, specialnummer av Arkiv. Tidskrift för samhällsanalys, nr 9.

DoI: https://doi.org/IO.13068/2000-6217.9

Fantasia, Rick (1988) Cultures of solidarity. Consciousness, action and contemporary American workers. Berkeley: University of California Press.

Foucault, Michel (2013) Biopolitikens födelse. Collège de France 1978-I979 (2008). Hägersten: Tankekraft.

Giddens, Anthony (1999) Tredje vägen. Om socialdemokratins förnyelse. Stockholm: Atlas.

Granberg, Magnus (2012) "Stormötesformen". Självorganisering i de vilda strejkerna. Rådsdemokrati, facklig decentralisering och arbetarkontroll 1969-1990. Opubl. magisteruppsats.

Granberg, Magnus (2016) Care in revolt. Labor conflict, gender, neoliberalism. Sundsvall: Mittuniversitetet.

Granberg, Magnus (20I7) "Shop floor power: Opportunity and collectivism in nurses' collective resignations", Nordic Journal of Working Life Studies volym 7, nr 4. DOI: https://doi.org/IO.I829I/njwls.v7i4.IO2360

Israel, Joakim (1964) Den vilda strejken. En fallstudie. Stockholm: Aldus/Bonnier.

Junesjö, Kurt (1998) Strejk. En demokratisk rättighet för bättre arbetsförhållanden. Stockholm: LO.

Järhult, Ragnar (1982) Nu eller aldrig. En bok om "den nya strejkrörelsen". Stockholm: Liber.

Karataşlı, Şahan Savaş, Sefika Kumral, Ben Scully \& Smriti Upadhyay (20I5) "Class, crisis, and the 2oII protest wave: Cyclical and secular trends in global labor unrest", i Immanuel Wallerstein, Christopher Chase-Dunn \& Christian Suter (red.), Overcoming global inequalities, s. I84-200. Boulder: Paradigm Publishers.

Karlbom, Rolf (1967) Hungerupplopp och strejker I793-1867. En studie $i$ den svenska arbetarrörelsens uppkomst. Lund: Gleerup.

Kelly, John (1998) Rethinking industrial relations. Mobilization, collectivism and long waves. New York: Routledge.

Kelly, John (2015) "Conflict: trends and forms of collective action", i Employee Relations volym 37 , nr 6, s. 720-732.

DOI: https://doi.org/IO.IIO8/er-06-2015-0IO2

Kings, Lisa (2014) "Förortens organisationer och kampen för förnyelse", i Fokus I4. Ungas fritid och organisering, s. I76-189. Stockholm: Myndigheten för ungdomsoch civilsamhällesfrågor.

Kjellberg, Anders (200I) "Arbetsgivarstrategier i Sverige under Ioo år”, i Carsten Strøby Jensen (red.), Arbejdsgivere i Norden. En sociologisk analyse af arbejdsgiverorganiseringen i Norge, Sverige, Finland og Danmark. Köpenhamn: Nordiska ministerrådet. 
Kjellberg, Anders (2016) "Partsrelationer och makt", i Margaretha Holmqvist (red.), Makt och inflytande i arbetslivet, s. 6o-86. Stockholm: Premiss.

Korpi, Walter (1974) Varför strejkar arbetarna? En sociologisk betraktelse över konflikter, makt och rätt på arbetsmarknaden. Stockholm: Tiden.

Korpi, Walter (1978) Arbetarklassen i välfärdskapitalismen. Arbete, fackförening och politik i Sverige. Stockholm: Prisma.

Korpi, Walter (I98I) Den demokratiska klasskampen. Svensk politik i jämförande perspektiv. Stockholm: Tiden.

Kouvelakis, Stathis (2003) Philosophy and revolution. From Kant to Marx. London: Verso.

Lundh, Christer (2002) Spelets regler. Institutioner och lönebildning på den svenska arbetsmarknaden I850-2000. Stockholm: SNS.

Mandel, Ernest (red.) (197I) Arbetarkontroll, arbetarråd, arbetarstyre. En antologi. Mölndal: Partisan.

Mandel, Ernest (1995) Long waves of capitalist development. A Marxist interpretation. London: Verso.

Marx, Karl (1973) Grundrisse: Foundations of the critique of political economy (rough draft). Harmondsworth: Penguin.

Marx, Karl (1975) "Den omedelbara produktionsprocessens resultat”, i Karl Marx \& Friedrich Engels, Ekonomiska skrifter. Skrifter i urval. Staffanstorp: Cavefors.

Marx, Karl (198I) Pariskommunen. Göteborg: Proletärkultur.

Marx, Karl (2018) Kapitalet. Kritik av den politiska ekonomin. Andra boken. Kapitalets cirkulationsprocess. Lund: Arkiv förlag.

Medlingsinstitutet (2017) Avtalsrörelsen och lönebildningen 20I6. Medlingsinstitutets årsrapport.

URL: https:/www.mi.se/app/uploads/AR_I6-I.pdf (I8 november 2020)

Montgomery, David (1979) Workers' control in America. Studies in the history of work, technology and labor struggles. Cambridge: Cambridge University Press.

Moody, Kim (2017) "U.S. workers in the late neoliberal era: The pressures, the changes, the potential", i New Politics volym I6, nr 3.

URL: https://newpol.org/issue_post/us-workers-late-neoliberal-era/ (I8 november 2020)

Ness, Immanuel \& Dario Azzellini (red.) (2011) Ours to master and to own. Workers' control from the commune to the present. Chicago: Haymarket.

Nycander, Svante (2002) Makten över arbetsmarknaden. Ett perspektiv på Sveriges Igoo-tal. Stockholm: SNS.

O'Kane, Chris (20I4) "State violence, state control: Marxist state theory and the critique of political economy", i Viewpoint Magazine nr 4.

URL: https://viewpointmag.com/20I4/Io/29/state-violence-state-control-marxiststate-theory-and-the-critique-of-political-economy/ (I8 november 2020)

Peterson, Abby, Håkan Thörn \& Mattias Wahlström (2018) "Sweden 1950-2015: Contentious politics and social movements between confrontation and conditioned cooperation", i Flemming Mikkelsen, Knut Kjeldstadli \& Stefan Nyzell (red.), Popular struggle and democracy in Scandinavia. I700-present, s. 377-432. London: Palgrave Macmillan. 
Rankin, Janet \& Marie Campbell (2009) "Institutional Ethnography (IE), nursing work and hospital reform: IE's cautionary analysis", i Forum: Qualitative Social Research volym Io, $\mathrm{nr} 2$.

DOI: https://doi.org/I0.17I69/fqs-IO.2.1258

Ross, Arthur M. \& Paul T. Hartman (I960) Changing patterns of industrial conflict. New York: Wiley.

Schierup, Carl-Ulrik, Aleksandra Ålund \& Lisa Kings (2014) "Reading the Stockholm riots - a moment for social justice?", i Race \& Class volym 55, nr 3, s. I-2I. DoI: https://doi.org/Io.II77/030639681350919I

Schiller, Bernt (1988) "Det förödande 70-talet". SAF och medbestämmandet 1965-I982. Stockholm: Arbetsmiljöfonden.

Screpanti, Ernesto (1987) "Long cycles in strike activity: an empirical investigation", i British Journal of Industrial Relations volym 25, nr I, s. 99-I24. DoI: https://doi.org/I0.IIII/j.I467-8543.1987.tboo703.x

Selberg, Rebecca (2012) Femininity at work. Gender, labour and changing relations of power in a Swedish hospital. Lund: Arkiv förlag.

Shorter, Edward \& Charles Tilly (1974) Strikes in France, I830-1968. London: Cambridge University Press.

Silver, Beverly (2003) Forces of labor. Workers' movements and globalization since 1870. Cambridge: Cambridge University Press.

Silver, Beverly (2013) "Theorizing the working class in twenty-first-century capitalism", i Maurizio Atzeni (red.), Workers and labour in a globalised capitalism. Contemporary themes and theoretical issues, s. 46-69. Basingstoke: Palgrave Macmillan.

Silver, Beverly \& Şahan Savaş Karataşlı (2015) "Historical dynamics of capitalism and labor movements", i Donatella della Porta \& Mario Diani (red.), The Oxford handbook of social movements, s. I33-I44. Oxford: Oxford University Press.

Smith, Jason E. (20I4) "Politics of the street: Commune and party in the age of riots", i South Atlantic Quarterly volym II3, nr 4, s. 687-700. DOI: https://doi.org/IO.I2I5/00382876-2803580

Sohn-Rethel, Alfred (1978) Intellectual and manual labour. A critique of epistemology. London: Macmillan.

Stokke, Torgeir A. \& Christer Thörnqvist (200I) "Strikes and collective bargaining in the Nordic countries", i European Journal of Industrial Relations volym 7, nr 3, s. 245-267. DoI: https://doi.org/IO.1177/0959680I0173002

Strömberg, Helén (2004) Sjukvårdens industrialisering. Mellan curing och caring - sjuksköterskearbetets omvandling. Umeå: Umeå universitet.

Svallfors, Stefan (2004) Klassamhällets kollektiva medvetande. Klass och attityder i jämförande perspektiv. Umeå: Boréa.

Svenskt Näringsliv (20I6) Varsel om stridsåtgärder på svensk arbetsmarknad 20II-20I5. URL: https://www.svensktnaringsliv.se/bilder_och_dokument/3lzk3r_varsel-omstridsatgarderpdf_I007049.html/Varsel+om+stridstgrder.pdf (I8 november 2020)

Svensson, Lennart (1984) Arbetarkollektivet och facket. En lokal kamp för företagsdemokrati. Lund: Studentlitteratur. 
Therborn, Göran (1975) Det svenska klassamhället 1930-70. Zenit särtryck nr 5.

Therborn, Göran (20I8 [198I]) Klasstrukturen i Sverige 1930-1980. Arbete, kapital, stat och patriarkat. Lund: Arkiv förlag. DOI: https://doi.org/IO.I3068/978917924324I

Thörnqvist, Christer (1994) Arbetarna lämnar fabriken. Strejkrörelser i Sverige under efterkrigstiden. Deras bakgrund, förlopp och följder. Göteborg: Göteborgs universitet.

Tilly, Charles (1976) "Major forms of collective action in Western Europe 1500-1975", i Theory and Society volym 3, nr 3, s. 365-375. DoI: https://doi.org/IO.IOO7/BFoor 59492

Toscano, Alberto (2014) "Lineaments of the logistical state", i Viewpoint Magazine nr 4. URL: https://viewpointmag.com/20I4/og/28/lineaments-of-the-logistical-state/ (I8 november 2020)

Tuuloskorpi, Francis (red.) (2015) Om strejker. Folkrörelse på arbetsplatsen, del 4. van der Velden, Sjaak (2016) Long waves in strike activity, I850-20I0. Recently published data and the search for new statistics. Opubl. manuskript. URL: https://pure.knaw.nl/ws/portalfiles/portal/5086083/Long_waves_in_strike_ activity.pdf (I8 november 2020)

van der Velden, Sjaak, Heiner Dribbusch, Dave Lyddon \& Kurt Vandaele (red.) (2007) Strikes around the world. Case-studies of IS countries. Amsterdam: Aksant.

Vandaele, Kurt (2016) "Interpreting strike activity in Western Europe in the past 20 years: the labour repertoire under pressure", i Transfer: European Review of Labour and Research volym 22, nr 3, s. 277-294. DoI: https://doi.org/IO.II77/I024258916658804

Wennerhag, Magnus (2017) "Patterns of protest participation are changing”, i Sociologisk Forskning volym 54, $\mathrm{nr} 4$, s. 347-351.

URL: https://sociologiskforskning.se/sf/article/view/I8234 (I8 november 2020)

Wennerhag, Magnus, Christian Fröhlich \& Grzegorz Piotrowski (red.) (2018) Radical left movements in Europe. Abingdon: Routledge. 


\section{KLASSISK KLASS- FORSKNING I ÅTERUTGIVNING}

GÖRAN THERBORN

Klasstrukturen i Sverige 1930-1980. Arbete, kapital, stat och patriarkat

I78 sidor

Therborns klassiska arbete om den svenska klasstrukturens utveckling under välfärdsepoken publicerades ursprungligen 198r. Den finns sedan 2018 åter tillgänglig i faksimilutgåva som både gratis e-bok och tryckt bok att köpa.

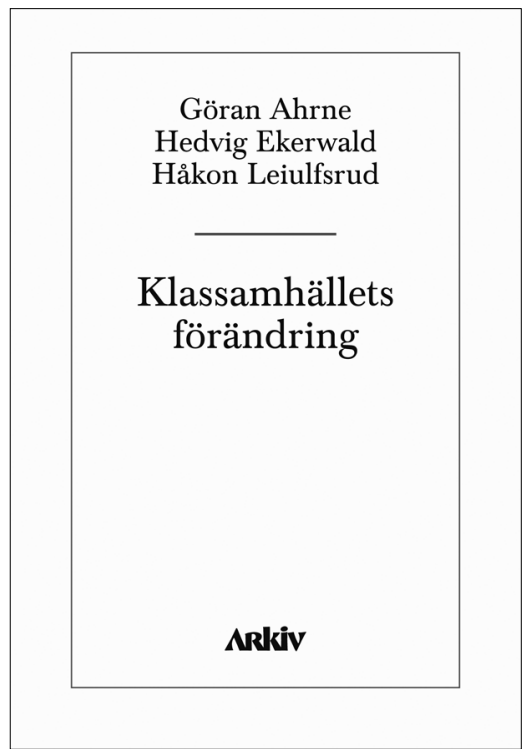

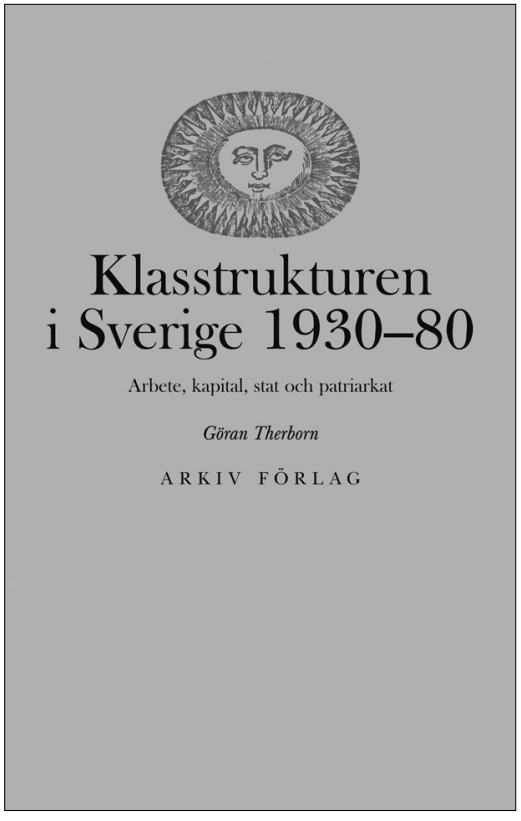

\section{SAMARBETE MED IDÉINSTITUTET KATALYS}

AHRNE, EKERWALD \& LEIULFSRUD Klassambällets förändring I30 sidor

Denna lättillgängliga och inflytelserika klassanalys gavs ursprungligen ut 1985. 2018 års faksimilutgåva återger den fjärde, utvidgade upplagans text från 1995 och finns som både gratis e-bok och tryckt bok att köpa. 